\title{
Strategi Maritime Silk Road China dan Dampaknya pada Keamanan Maritim Indonesia
}

\author{
Ismah Rustam ${ }^{1}$ \\ ${ }^{1}$ Program Studi Hubungan Internasional, Universitas Mataram, NTB, Indonesia \\ ismahrustam@unram.ac.id
}

\begin{abstract}
Nowadays, China has become one of the countries that reveal an increasing of power capability on military, economic and expanding geopolitics. Under the leadership of President Xi Jinping, China developed many innovations that based on long-held fundamental concepts such as the "Chinese dream", "The Great Rejuvenation of The Chinese Nation" and the "Twin Century Goals". One of the newest Chinese ideas is to reformulate China's Silk Road into the Belt and Road Initiative, which combines land and sea routes as the main trade route extending to Europe. This paper tries to describe how the Maritime Silk Road as part of the megaproject has an aim of being the driving of China's blue economy through the idea of blue partnership with the main route through Indonesian territory. By using the concept of maritime security and considering the South China Sea area which full of disputes, as well as the acts of China that violated Indonesia's sovereignty. Therefore, this initiative has become a challenge for Indonesia's maritime security.
\end{abstract}

Keywords: China, Indonesia, Maritime Security, Maritime Silk Road.

\begin{abstract}
ABSTRAK
Dewasa ini, China menjadi salah satu negara yang menunjukkan peningkatan kapabilitas kekuatan baik militer, ekonomi, dan geopolitiknya yang semakin meluas. Dibawah kepemimpinan Presiden Xi Jinping, China mengembangkan banyak inovasi yang berlandaskan konsep fundamental yang dipegang teguh sejak dulu seperti "Chinese Dream", "the great rejuvenation of the Chinese nation" serta "the twin centenary goals". Salah satu gagasan China terbaru adalah mereformulasi Jalur Sutera Kuno China menjadi Belt and Road Initiative, yang menggabungkan jalur darat dan jalur laut sebagai jalur perdagangan utama yang membentang hingga ke Eropa. Jalur maritim China memiliki tujuan menjadi penggerak blue economy China melalui ide blue partnership. Peta maritime Silk Road yang dibuat China memperlihatkan jalur yang melewati wilayah Indonesia. Mempertimbangkan wilayah teritorial LCS yang penuh sengketa dan beberapa kali China kedapatan melakukan pelanggaran di laut Indonesia, maka inisiatif ini memberikan tantangan bagi keamanan maritim Indonesia.
\end{abstract}

Kata Kunci: China, Indonesia, Keamanan Maritim, Maritime Silk Road.

\section{PENDAHULUAN}

China merupakan negara maju yang menunjukkan berbagai perkembangan pesat dalam industri militer, pasar ekonomi, perdagangan, kemajuan insfrastruktur dan modernisasi lainnya. Sehingga negara ini berani memainkan banyak peran penting di regional baik kawasan Asia Timur maupun Asia Pasifik. Pada tanggal 3 Oktober 2013, Presiden Xi Jinping mengumumkan secara resmi konsep Jalur Sutera Maritim Abad ke-21 di depan Parlemen Indonesia, Inti kebijakan tersebut adalah pembangunan infratsruktur transportasi laut dari daratan China menuju pelabuhan-pelabuhan utama di berbagai negara Asia Tenggara, Asia Selatan, Timur Tengah, Afrika, dan Eropa. Selain itu, China bahkan menuntaskan ambisinya dengan memadukan jalur laut dan 
darat melalui strategi barunya yang disebut sebagai Belt and Road Initiative (BRI) (Suropati et al., 2016, p. 66).

Dalam perkembangan regional maupun internasional saat ini, China memiliki pengaruh kuat di berbagai kawasan. Dalam klaim wilayah teritorial, Beijing berhadapan dengan berbagai negara tetangga yang mempunyai penetapan batas wilayah teritorial yang tidak menemukan jalan sepakat dengan China. Namun, di satu sisi China masih sangat membutuhkan negara-negara tetangga seperti ASEAN sebagai partner dalam berbagai bidang. China masih butuh untuk mempromosikan political trust dengan negara-negara Asia Tenggara; dalam ranah politik mencoba untuk meng-upgrade hubungan ASEAN-China dari sebuah 'strategic partnership' menjadi 'community of shared destiny'. China ingin membangun kembali the 21st Century Maritime Silk Road untuk memudahkan akses bagi China masuk ke berbagai pelabuhan utama di Asia Tenggara (Huy Hoang, 2017).

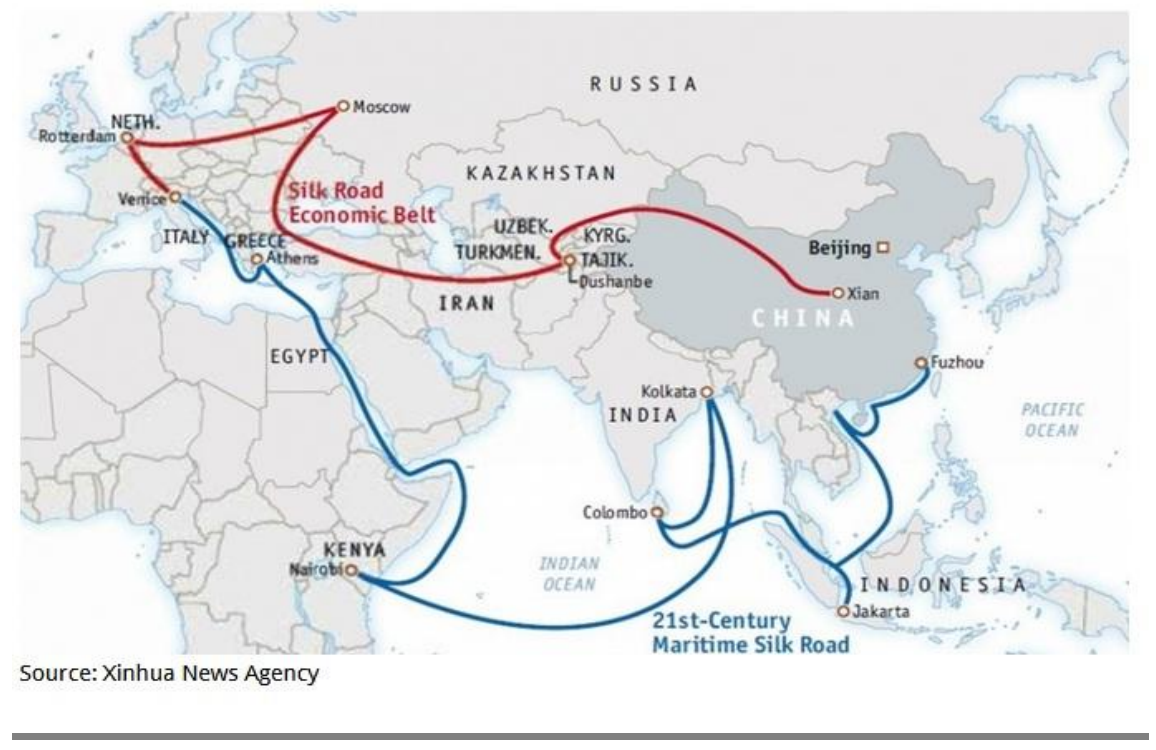

Gambar 1. Inisiatif 'Belt and Road' China (Xinhua Net, 2018)

Kemajuan China dengan berbagai bidang menunjukkan adanya kebangkitan kembali dari yang sebelumnya tenggelam dibawah unipolar negara super power Amerika Serikat (AS). China hari ini 'hidup' kembali dengan laju ekonomi rata-rata diatas 7\%. Bahkan riset Standard Chartered Bank tahun 2010 memprediksikan bahwa pada tahun 2030 kekuatan ekonomi China akan menggeser dominasi AS ke urutan kedua. China's Maritim Silk Road Initiative (MSRI) dan the Silk Road Economic Belt (SREB) menjadi dua agenda yang saling berkoneksi dalam "Belt dan Road". Proyek konektivitas ini sedang gencar disosialisasikan China karena melibatkan komponen infrastruktur secara masif yang menghasilkan kontroversi mengenai potensi China untuk ditransformasi kedalam lanskap geopolitik global (Blanchard \& Flint, 2017).

Dalam strategi jalur maritim China akan membangun navigasi dan berbagai fasilitas keamanan. Dalam jalur yang dibuat China tersebut akan bersentuhan dengan Indonesia bagian utara yaitu Laut Natuna Utara yang berbatasan langsung dengan Laut China Selatan. Laut ini merupakan laut sengketa antara China dengan negaranegara ASEAN. Pada Laut Natuna dan sekitarnya, Indonesia mempunyai peluang 
ekonomi maritim yang cukup besar. Lebih dari 50\% cadangan dan produksi minyak Indonesia berasal dari provinsi Riau. Selain sumber daya minyak dan gas bumi, laut Natuna juga menjadi sumber perikanan tangkap dan budidaya. Potensi kekayaan alam di perairan ini perlu mendapatkan jaminan keamanan maritim yang menyeluruh. Mengingat Indonesia berada dalam posisi sangat strategis dalam dua pengaruh global dunia; AS dan China, maka harus mampu memberikan respon yang strategis terutama dalam proteksi keamanannya (Suropati et al., 2016, p. 66).

Sebagai sebuah bangsa bahari, kebijakan Indonesia dibawah kepemimpinan Presiden Joko Widodo berkeinginan mengembalikan jati diri bangsa Indonesia sebagai sebuah negara maritim yang tangguh sehingga konsep negara poros maritim dunia harus benar-benar ditampilkan. Gagasan Indonesia sebagai negara Poros Maritim pun telah disampaikan dalam forum internasional Konferensi Tingkat Tinggi Negara-negara Asia Timur (KTT EAS) di Myanmar dengan gamblang menjabarkan mengenai visi kelautan Indonesia yang bebas ancaman (Tempo.co, 2014). Tulisan ini ingin menjelaskan mengenai peta strategi Maritime Silk Road China yang bersinggungan dengan wilayah perairan Indonesia dan dampaknya terhadap situasi keamanan maritim. Karena ekspansi Maritime Silk Road China yang melewati perairan Indonesia menjadi tantangan sekaligus peluang. Menciptakan keamanan maritim di seluruh wilayah Indonesia adalah prioritas yang harus diutamakan.

\section{TINJAUAN PUSTAKA}

Penelitian dan tulisan mengenai studi kajian maritim internasional serta keamanan memang telah banyak dilakukan. Namun masih sedikit literatur yang secara khusus mendeskripsikan situasi keamanan Indonesia sebagai negara kepulauan dilihat dari potensi geostrategis dan geopolitik kawasan, terlebih dari berbagai kebijakan negara besar seperti China yang memanfaatkan situasi perkembangan kawasan untuk mencapai kepentingannya. Terdapat sejumlah literatur yang berkenaan dengan pokok masalah yang akan dikaji dalam penelitian ini.

\section{POLITIK KELAUTAN}

Syamsumar Dam menjelaskan mengenai Istilah Politik Kelautan (Ocean Politics) pertama kali digunakan oleh Peter Polomka melalui bukunya Ocean Politics in Southeast Asia yang diterbitkan oleh ISEAS Singapore pada tahun 1978. Ketika sedang berlangsung Konferensi Hukum Laut Ke-III yang diselenggarakan oleh PBB (1974-1982) yang akhirnya menghasilkan Konvensi Hukum Laut Internasional 1982. Kajian Polomka lebih menitikberatkan pada masalah kelautan yang berkembang selama konferensi, khususnya di wilayah Asia Tenggara. Menurutnya, dewasa ini lautan menjadi pusat perhatian dari negara-negara bangsa (nation states) dan perusahaan transnasional untuk memperoleh kekayaan, kekuasaan, dan prestise. Ditambahkan pula, eksploitasi lautan oleh berbagai pihak telah menimbulkan berbagai masalah kontemporer seperti masalah politik, hukum, ekonomi, lingkungan, dan teknologi. Bahkan lautan telah dijadikan sebagai isu dasar dalam saling ketergantungan antarnegara serta stabilitas dan kemakmuran global dalam jangka panjang. 
Dijelaskan berdasarkan teori Barry Buzan, dalam tiga dekade terakhir sejak Perang Dunia II, lautan telah menjadi suatu sumber pertikaian dan konflik antar negara yang begitu penting. Lautan tidak saja dipergunakan sebagai arena untuk mempertajam perbedaan kepentingan nasional dalam hubungan internasional, tetapi juga sudah merupakan sumber kekacauan yang sudah semakin meluas dalam sistem internasional. Kerisauan para pakar dan tokoh politik internasional di atas, dipengaruhi pula oleh perubahan hubungan internasional sejak berakhirnya Perang Dunia II, baik dalam aspek politik internasional, maupun dalam aspek hukum laut internasional (Dam, 2010: 2). Perubahan politik internasional ditandai oleh perubahan konfigurasi politik internasional dari bipolar yang diperlihatkan oleh persaingan pengaruh kedua negara adi kuasa (super power) seperti AS dan US dalam bentuk Perang Dingin (1947-1989) menjadi multipolar yang ditandai oleh kehadiran aktor-aktor utama yang baru seperti Uni Eropa, Jepang, China, dan India.

\section{POTENSI LAUT CHINA SELATAN}

Parulian Simamora menjelaskan mengenai Laut China Selatan adalah sebuah kawasan yang setengah wilayahnya ditutupi oleh air dan dikelilingi sembilan negara dengan klaim saling tumpang tindih zona maritim laut, pulau-pulau kecil dan karang. Rantai kepulauan utamanya adalah pulau-pulau Paracel dan pulau-pulau Spratly. Pulau-pulau Paracel diklaim oleh Cina dan Vietnam sedangkan pulau-pulau Spratly di klaim oleh Filipina, Malaysia, Brunei dan Taiwan, termasuk Cina dan Vietnam juga. Klaim Cina dan Vietnam atas Laut China Selatan berdasarkan sejarah, Filipina berdasarkan kedekatan geografis, Malaysia berdasarkan sejumlah karang yang masuk dalam landasan kontinennya (continental shelf), sedangkan Brunei berdasarkan Zona Ekonomi Eksklusifnya. Untuk memperkuat klaimnya, masing-masing negara melakukan berbagai cara, antara lain: menempatkan pasukan di pulau yang diklaim, mendatangkan turis, melakukan patroli dan peninjauan, membuat peta yang menunjukan wilayah tersebut sebagai bagian dari wilayahnya.

Laut China Selatan kaya akan sumber daya yang menjadi rebutan oleh beberapa negara yang mengelilingi laut tersebut karena dapat menjadi sumber energi dan kemakmuran bagi rakyatnya. Konsumsi energi China semakin meningkat untuk mempertahankan pertumbuhan ekonominya antara $8-10 \%$ per tahun. China mengklaim hampir seluruh kawasan Laut China Selatan sebagai bagian dari wilayahnya, yang terkenal dengan sebutan meletakkan sembilan garis titik $(9$ dotted lines). Klaim sepihak oleh China atas seluruh kawasan ini, telah membuat negaranegara yang ikut mengklaim menjadi gusar dan melakukan kegiatan-kegiatan untuk memperkuat klaimnya serta membangun dan memperkuat angkatan bersenjatanya. Walaupun telah banyak, upaya-upaya yang dilakukan untuk menyelesaikan konflik, namun klaim dari negara-negara yang terlibat didalamnya, hingga saat ini terus berlanjut dan berpotensi memicu konflik di masa datang.

Potensi konflik ini perlu diredam untuk memelihara stabilitas dan keamanan di kawasan Laut China Selatan (Simamora, 2014). Apabila dilihat dari aspek pertahanan dan keamanan, bagi Indonesia kawasan Laut China Selatan dapat menjadi ancaman apabila: pertama, terjadi konflik bersenjata antar negara yang saling bertikai; kedua, terjadinya perlombaan senjata atau pembangunan kekuatan angkatan bersenjata secara signifikan di kawasan yang bertikai; dan ketiga, terlibatnya dua kekuatan besar 
Amerika Serikat dan China dalam konflik Laut China Selatan. Menjadi peluang bagi Indonesia sebagai juru runding atau penengah atau penyeimbang apabila masingmasing negara yang bertikai sadar dan bersedia untuk melakukan perundingan atau kerja sama di kawasan yang dipersengketakan (Simamora, 2014).

\section{JALUR SUTERA MARITIM CHINA}

Dalam buku yang berjudul "Arungi Samudra Bersama Sang Naga; Sinergi Poros Maritim Dunia dan Jalur Sutera Maritim Abad ke-21", Untung Suropati, Yohanes Sulaiman dan lan Motratama. Menjabarkan bahwa pada tahun 2013, presiden China, Xi Jinping, secara resmi meluncurkan kebijakan Jalur Sutera Maritim Abad ke 21. Menariknya, peluncuran kebijakan tersebut dilakukan di depan parlemen Indonesia. Untuk merealisasikan ambisinya, China berkomitmen menyediakan dana tidak kurang dari US\$ 40-45 miliar untuk pembangunan infrastruktur, terutama pelabuhan laut di berbagai lokasi strategis sepanjang rute Jalur Sutera Maritim yang terbentang dari daratan China hingga ke Afrika dan Eropa (Suropati et al., 2016).

Tentu saja kebijakan Jalur Sutera Maritim Abad ke 21 memanfaatkan program bantuannya sebagai alat untuk menebar pengaruh ke negara-negara lain, terutama negara penerima bantuan. Hal ini terlihat dari inisiatif China mendirikan AllB yang merupakan lembaga pemberi pinjaman untuk proyek-proyek pembangunan infrastruktur terkait kebijakan OBOR, dimana kebijakan Jalur Sutera Maritim Abad ke 21 ada di dalamnya, pada tanggal 29 Juni 2015. Tidak aneh kelahiran AllB menjadi daya tarik luar biasa bagi banyak negara, terutama negara-negara yang memerlukan dana bagi pembangunan infrastruktur konektivitas maritimnya. Sementara bagi negara kreditor, banyaknya negara debitur membuka peluang masuknya perusahaanperusahaan negaranya menanam berbagai proyek infrastruktur di negara tersebut.

Sebagaimana diketahui klaim China yang sejauh ini berdasar sejarah, disamping tidak sesuai dengan tata pergaulan internasional, juga sebenarnya sangat subyektif, yakni bahwa perairan tersebut pernah disinggahi pelaut-pelaut China. Sebagaimana telah diatur dalam UNCLOS 1982 bahwa kedaulatan atas wilayah laut tertentu diukur berdasar jarak dari titik atau pulau terluar suatu negara. Namun, sebagaimana telah dibahas di atas bahwa seiring dengan semakin menguatnya ekonomi dan militer China, negara itu pun merasa perlu bersikap lebih asertif dalam membela apa yang dianggapnya sebagai bagian dari keutuhan wilayah, termasuk dengan mempertahankan klaimnya yang jauh melebihi batas aturan hukum laut internasional.

Sementara Indonesia, merasa dirinya bukan sebagai negara penuntut, cenderung memilih bermain di zona aman. Suatu sikap yang sangat disayangkan banyak kalangan, terutama Filipina dan Vietnam, mengingat Indonesia adalah pemimpin alamiah kawasan. Merasa Indonesia tidak bisa diharapkan, Filipina pun berusaha melibatkan ASEAN. Namun, upaya Filipina membawa kasus Laut China Selatan ke forum KTT ASEAN di kamboja tahun 2012 pun mengalami hambatan. Kegagalan Filipina tidak lain karena ditentang oleh sesama anggota ASEAN sendiri yaitu Kamboja, yang dikenal memiliki hubungan sangat erat dengan China. Pertama dalam sejarah ASEAN, forum setingkat KTT hamper gagal menyepakati joint communiqué (Suropati et al., 2016). 
Oleh karena itu, tantangan ASEAN di masa depan sangatlah besar. Kegagalan dalam penyelesaian masalah sengketa perbatasan, seperti yang terjadi di Laut China Selatan yang melibatkan beberapa negara anggota ASEAN vs China melalui forum ASEAN, dipastikan akan sangat menurunkan kredibilitas, sekaligus soliditas ASEAN. Hal tersebut mulai terasa manakala Vietnam dan Filipina cenderung lebih mendekat ke Amerika Serikat dalam menghadapi sengketa perbatasannya dengan China di Laut China Selatan. Pada saat yang sama sebagai sesama negara ASEAN, Laos, Kamboja, dan Myanmar lebih condong ke China. Tidak ketinggalan sikap negara ASEAN yang lain seperti Malaysia dan Singapura. Sebagai negara penuntut, Malaysia cenderung mengesampingkan posisi berlawanan dengan China karena memiliki kepentingan ekonomi yang besar dengan Beijing, sementara Singapura, lebih menampilkan sikap abu-abu (dalam balutan strategi luar negeri hedging (Suropati et al., 2016).

Melihat jabaran tinjauan pustaka di atas, dapat disimpulkan bahwa setiap negara memainkan politik maritim guna mendukung berbagai kepentingan mereka di lautan, termasuk bagi negara-negara yang tidak memiliki laut. Strategi politik kelautan juga semakin berkembang luas hingga hari ini. Salah satunya kepentingan negara China dan situasi konfliktual di Laut China Selatan. Pada literatur terakhir dipaparkan mengenai ide poros maritim Indonesia yang bersamaan dengan berjalannya gagasan jalur sutera maritim China, namun kajian yang fokus membahas mengenai ancaman dari China khususnya pada wilayah laut Indonesia secara spesifik di kawasan masih belum banyak ditemukan. Karenanya perlu diadakan kajian lebih lanjut dan bersifat komprehensif untuk menggali potensi-potensi dan masukan-masukan untuk kajian kemaritiman dalam hubungan internasional.

\section{METODE PENELITIAN}

Penelitian ini menggunakan teknik kualitatif, sebagaimana yang dideskripsikan oleh Creswell bahwa teknik penulisan kualitatif sebagai sebuah proses dimana masalah penelitian menjadi sebuah studi yang muncul dari natural setting seperti pengumpulan data lapangan yang dikaji dengan berbagai metode, bukan sebuah studi yang muncul dari penelitian laboratorium. Sehingga pada saat proses koleksi informasi dengan teknik kualitatif dapat diperoleh dari berbagai sumber guna memahami bagaimana pemecahan permasalahan baik melalui responden atau orang-orang yang terlibat (Creswell, 2007). Penulis menggunakan teknik penelitian kualitatif yang bersifat deskriptif dengan mengumpulkan data dari berbagai sumber data seperti buku dan literatur jurnal, hasil seminar mengenai Belt and Road Initiative yang disampaikan pada Seminar on South-south Cooperation di Beijing, China, maupun pemberitaan media massa seperti koran Tempo dan tulisan terpublikasi yang meneliti mengenai tema serupa.

Adapun urutan analisis data yang dilakukan dengan metode kualitatif adalah pertama, peneliti membaca berkali-kali data yang diperoleh dari studi pustaka sambil menghilangkan beberapa informasi yang tumpang tindih atau berulang-ulang disebutkan. Kedua, melihat signifikansi atau pentingnya data yang diperoleh. Ketiga, mengklasifikasikan data yang memiliki kemiripan atau kecocokan dengan data lain. Keempat, mencari pola atau tema yang mengikat pikiran yang satu dengan lainnya. Kelima, mengkonstruksikan framework untuk mendapatkan esensi dari apa yang hendak disampaikan oleh data tersebut (Raco, 2010). 


\section{KERANGKA PEMIKIRAN}

Penelitian ini menggunakan kerangka konsep keamanan maritim. Keamanan maritim sendiri didefinisikan oleh Bueger sebagai sebuah kondisi dimana tidak terdapat bentuk ancaman apapun. Ancaman yang dimaksud antara lain perselisihan antar negara terutama dalam klaim yurisdiksi di wilayah perairan, kemudian ancaman kegiatan terorisme di laut, masalah pembajakan kapal, masalah kejahatan terorganisir seperti penyelundupan narkoba, penyelundupan manusia, dan barang-barang ilegal lainnya, juga ancaman illegal fishing, masalah lingkungan, hingga ancaman kecelakaan di laut dan bencana (Bueger, 2015).

Guna mempermudah memahami sebuah kondisi keamanan maritim, Bueger mencoba menggambarkan situasi dalam sebuah matrik dimana memuat empat pilar utama untuk menopang situasi aman. Pertama, marine environment yaitu situasi dimana wilayah laut dalam keadaan aman ketika bebas dari bahaya kecelakaan pelayaran, polusi lingkungan dan perubahan iklim, sebab masalah lingkungan berkaitan dengan masa depan kehidupan bawah laut. Kedua, keamanan maritim erat kaitannya dengan economic development karena negara-negara saat ini menghadirkan blue economy sebagai alternatif dalam pembangunan berkelanjutan, maka dalam matrik ini keadaan aman ialah saat bebas dari ancaman kegiatan penyelundupan, IUU fishing dan pembajakan kapal sebagai penghambat pembangunan ekonomi sebuah negara maritim.

Ketiga, national security yang lebih condong pada upaya penegakan kedaulatan di laut sebuah negara dimana keamanan akan tercipta apabila terbebas dari berbagai insiden perselisihan antar negara baik masalah klaim wilayah teritorial, masalah perbatasan laut hingga proliferasi senjata. Matriks keempat ialah human security, dimana ancaman terhadap keamanan manusia semakin meningkat, misalnya maraknya praktek human trafficking. Kerangka konsep keamanan maritim yang dijabarkan oleh Bueger hampir mirip dengan dengan Geoffrey Till bahwa keamanan maritim sebagai frasa baru yang tidak hanya bersifat tradisional seperti sea control atau expeditionary operations namun kini lebih berkembang isu non-tradisional dalam upaya pemeliharaan tatanan wilayah laut sebagai ruang yang menyimpan potensi sumber daya alam, pelayaran dan lingkungan hidup (Till, 2004).

Kedua pendekatan di atas menjadi kerangka pemikiran dalam tulisan ini. Situasi keamanan maritim dalam sebuah negara tidak dapat terwujud bilamana salah satu aspek ancaman masih terjadi. Meminjam dari matriks keamanan maritim Bueger, bahwa salah satu sektor yang terpenting adalah keamanan nasional. Dimensi ini bertumpu pada perspektif tradisional untuk memberikan perlindungan pada seluruh wilayah teritorial negara, seperti Indonesia yang memiliki ruang laut lebih luas daripada daratan, sehingga titik terluar negara kepulauan adalah wilayah perairan. Apabila masih terjadi pelanggaran dalam wilayah teritorial, dalam hal ini Indonesia, maka belum dapat dikatakan terdapat situasi keamanan maritim karena sejumlah ancaman pelanggaran wilayah. Dalam dimensi lainnya, Bueger juga menunjukkan bahwa keamanan ekonomi dan keamanan lingkungan tidak kalah pentingnya, hal ini senada dengan ruang maritim Indonesia khususnya wilayah Laut Natuna Utara hingga ke Selat Malaka yang memiliki nilai komersialisasi tinggi dan mempunyai potensi ancaman dalam dimensi tersebut terutama menghadapi rencana megaproyek China. 
Wilayah teritorial Indonesia yang berada dalam pekarangan Asia Tenggara merupakan area strategis tempat bertemunya banyak kepentingan strategis. Dalam hubungan konfliktual maritim dapat terlihat bagaimana China dan para negara claimant states beradu kekuatan di Laut China Selatan yang masing-masing mengedepankan kepentingan mempertahankan wilayah teritorialnya. Hal ini menunjukkan aspek tradisional dalam studi keamanan maritim seperti yang dikemukakan dalam konsep Bueger maupun Till masih relevan dengan keadaan sekarang. Disaat negara-negara Asia Tenggara tengah beradu klain wilayah di Laut China Selatan, China membangun megaproyek di sepanjang laut mulai dari pesisir China Hingga tembus ke Samudra Hindia dengan berbagai konsekuensi keamanan maritim yang harus diterima negaranegara pesisir. Termasuk situasi keamanan maritim di Indonesia dan negara-negara di kawasan.

\section{PERKEMBANGAN EKONOMI CHINA DAN KEMUNCULAN INISIATIF BELT AND ROAD}

China merupakan negara paling berpengaruh di Asia saat ini. Kebangkitan China tentu tak lepas dari keberhasilan reformasi ekonomi yang dilakukan sejak tahun 1978. Sejak peralihan masa jabatan dari tangan Mao Zedong ke Deng Xiaoping. Pada masa pemerintahan Deng Xiaoping kebijakan ekonomi China berubah drastis dengan mulai menerapkan sistem ekonomi pasar dan melakukan transisi ideologi dari Maoisme yang terbukti gagal menyejahterakan rakyatnya (Suropati et al., 2016, p. 66). China bergabung dalam beberapa integrasi regional di berbagai kawasan.

Tahun 1997-1998 terjadi krisis finansial di Asia secara besar-besaran dan berdampak pada hampir semua negara sehingga peningkatan integrasi perdagangan dan investasi sangat terlihat sejak saat itu. China mulai memposisikan diri dimana Presiden Xi Jinping menerapkan konsep "Chinese Dream", "the great rejuvenation of the Chinese nation" serta "the twin centenary goals" sejak kepemimpinannya. Dengan slogan-slogan tersebut China diharapkan mampu bangkit hingga menjadi pesaing baru bagi negara-negara barat (Johnson et al., 2016). Presiden Xi Jinping membuat banyak inovasi dengan berbagai konsep yang dirancang dengan sebuah target yaitu pada tahun 2049 menjadi negara utama yang berpengaruh di kawasan.

China mengalami perkembangan pesat sejak memasuki abad ke-21. Ini disebut sebagai gelombang Rising China yang berlangsung secara bertahap. Pertama, peletakan landasan domestiknya yang didasari pertanian, dengan menutup diri dari pengaruh asing. Hal ini menyebabkan pada era Mao Zedong, China dikenal dengan sebutan negara Tirai-bambu. Kedua, keterbukaan yang berlandaskan pada industrialisasi, pertama kalinya dilakukan oleh Deng Xiao Ping. Ketiga, keterbukaan yang bukan hanya sekedar membuka pintu terhadap kehadiran investasi asing, namun juga menjadi pelaku utama investasi ke berbagai kawasan. Ini yang dilakukan oleh Xi Jinping sejak tahun 2013 melalui strategi ekonomi lintas kawasan atau yang kita kenal dengan Belt and Road initiative (BRI). Ini merupakan strategi jangka panjang dengan mereformulasi dari Jalur Sutera Kuno yang membuat suatu jalur perdagangan dan energi membentang dari China hingga ke Eropa dan Afrika (Jati, 2017). 


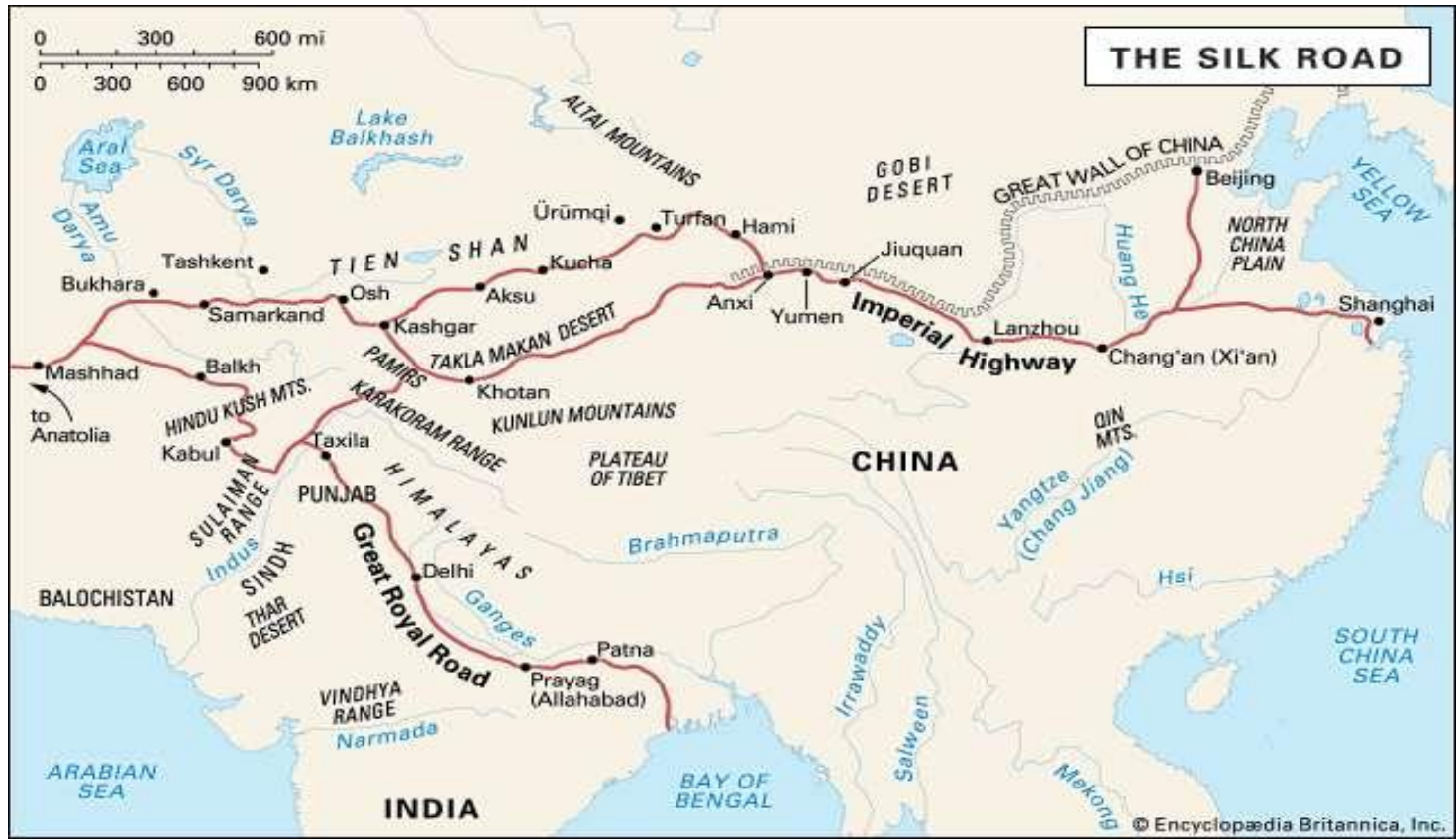

\section{Gambar 2. Peta Jalur Sutera Kuno China (The Editors of Encyclopaedia Britannica, 2018).}

BRI merupakan gabungan dari dua konsep yang membentang dalam jalur sutera daratan dan jalur sutera lautan. Jalur sutera telah berlangsung sejak berabadabad lamanya yang menghubungkan antara China dengan barat (lihat gambar 2). Semangat dari Jalur Sutera Kuno yang saat itu berkembang yaitu "peace and cooperations, openness and inclusiveness, mutual learning and mutual benefit". Hal ini masih tetap dipertahankan hingga saat ini. Jalur sutera mengikat hubungan erat antara timur dan barat, menjadi simbol kerjasama dan komunikasi. Jalur sutera adalah sebuah sejarah dan warisan budaya yang diakui oleh semua negara di dunia (Zou Weikang, 2018). Dalam catatan sejarahnya, China memang memberikan perhatian terhadap laut. Hal ini digambarkan dalam ekspedisi lautan yang dilakukan oleh Laksamana Cheng Ho ke Laut China Selatan pada masa Dinasti Ming pada abad ke14 dengan memanfaatkan kepulauan Paracel dan Spratly sebagai tempat persinggahan (Dam, 2010).

BRI sebagai gagasan lama dari jalur sutera China yang kini kembali dicetuskan dengan kepentingan yang jauh lebih luas daripada sekedar perdagangan. Gagasan ini tentu memberi implikasi yang cukup besar terhadap ekonomi dan politik di kawasan. Bukan hanya terhadap China, namun juga negara-negara yang berada dalam kawasan Asia. Bagi China saat ini dunia tengah dihadapkan dengan tuntutan untuk menciptakan perdamaian, pembangunan, kerjasama dan juga saling memberi keuntungan. Melakukan kompetisi yang menimbulkan kerugian harus dihindari. Hal ini yang mendorong semangat reformulasi belt and road China untuk menghadapi situasi ekonomi global dan tantangan internasional yang begitu kompleks.

Dukungan jalur sutera maritim China salah satunya adalah untuk mengembangkan konsep Blue Economy yang berorientasi pada industri kelautan dan pemanfaatan sumber daya laut secara maksimal. Sementara itu, negara-negara Barat 
masih meletakkan konsentrasi pada pembangunan lingkungan berkelanjutan dengan berbagai upaya politik hijau. Termasuk mengekang China sebagai negara yang menyumbangkan polusi dalam jumlah besar terhadap kehidupan bumi(Ghiasy et al., 2018). Dalam inisiatif BRI, jalur sutera maritim China adalah salah satu prioritas utama pembangunan kekuatan laut negara tirai bambu tersebut. Selain kepentingan untuk melindungi kedaulatan teritorial China, kepentingan untuk melindungi wilayah strategis industri sepanjang pantai, kepentingan untuk melindungi sumber daya laut serta keamanan pelayaran dan jalur komunikasi untuk melancarkan perdagangan internasionalnya.

\section{JALUR SUTERA MARITIM CHINA SEBAGAI JALUR PELAYARAN INTERNASIONAL}

Pasca Perang Dingin, China melakukan gebrakan diplomasi untuk memperbesar kapasitas proyeksi kekuatan militernya melalui kerjasama sepanjang jalur laut untuk memberikan kelancaran pada sirkulasi sejumlah kepentingan nasionalnya. Mereformulasi sebuah konsep jalur laut sebagaimana jalur sutera China di masa lalu yang lebih dahulu eksis. Sebelum konsep ini dikenal dengan nama Jalur Sutera Maritim, strategi ini dikenal dengan nama untaian mutiara (string of pearls) meskipun konsep ini tidak pernah dianggap sebagai kebijakan formal pemerintah China (Suropati et al., 2016, p. 108). Kemajuan pesat China dalam bidang ekonomi juga bersamaan dengan kemajuan dalam bidang militer dan politik, sehingga China nampak memiliki agresivitas di kawasan Asia termasuk di Asia Tenggara dan disebut sebagai "the next regional hegemon" oleh Mearsheimer. China akan memilih jalan menjadi negara hegemon dalam situasi internasional yang anarki (Mearsheimer, 2001).

Hampir 90 persen total perdagangan internasional China diangkut melalui laut, perdagangan maritim merupakan mesin utama untuk mempertahankan ekonomi nasional China. Melalui 'Blue Partnership', China dapat mengekspor kelebihan kapasitas industrinya ke pasar luar negeri dan menstimulus sumber-sumber baru untuk pertumbuhan ekonomi domestik. China secara aktif telah mempunyai hak kepemilikan pelabuhan asing di sepanjang jalur-jalur strategis. China melakukan ekspansi ekonomi dengan membangun pelabuhan-pelabuhan di sejumlah negara di Laut China Selatan dan Samudra Hindia (lihat Tabel 1). Pembangunan Infrastruktur pelabuhan di sepanjang jalur maritim dimaksudkan untuk merangsang pertumbuhan blue economy karena dengan adanya pelabuhan akan memudahkan koneksi dengan sejumlah area daratan di China seperti Pelabuhan Gwadar di Pakistan dan Kyaukpyu di Myanmar. Sejumlah pelabuhan China di negara lain didirikan untuk menstimulasi perkembangan ekonomi terestrial China dengan menghubungkan provinsi pedalaman China yang kurang berkembang melalui koridor ekonomi sepanjang jalur maritim ke Samudra Hindia. 
Tabel 1. Pelabuhan Milik China di Negara-Negara Laut China Selatan dan Samudra India (Ghiasy et al., 2018)

\begin{tabular}{lllll}
\hline Year & Region & Host state & Port & Lease period \\
\hline 2015 & Indian Ocean & Pakistan & Gwadar & 40 years \\
2015 & Indian Ocean & Myanmar & Kyaukpyu & 50 years \\
2015 & South China Sea & Malaysia & Kuantan & 60 years \\
2016 & Indian Ocean & Djibouti & Obock & 10 years \\
2016 & South China Sea & Malaysia & Melaka Gateway & 99 years \\
2017 & Indian Ocean & Sri Lanka & Hambantota & 99 years \\
2017 & South China Sea & Brunei & Muara & 60 years \\
2017 & Indian Ocean & Maldives & Feydhoo Finolhu & 50 years \\
\hline
\end{tabular}

Note: Transparency issues mean that data on the year of agreement and lease period may be inaccurate.

Sources: Data compiled by the authors from various sources.

Presiden China Xi Jinping secara resmi telah meresmikan kebijakan Jalur Sutera Maritim Abad ke-21. Untuk merealisasikan ambisinya, China berkomitmen menyediakan dana tidak kurang dari US\$ 40-45 miliar untuk pembangunan infrastruktur, terutama pelabuhan laut di berbagai lokasi strategis sepanjang rute Jalur Sutera Maritim yang terbentang dari daratan China hingga ke Afrika dan Eropa. Target perdagangan China bukan hanya di Asia tetapi tujuan utama adalah negara-negara di Eropa dengan melalui Laut Mediterania dan terusan Suez. sejumlah negara di Afrika menjadi sasaran China seperti Djibouti, Kenya, Madagaskar, Mozambik dan Tanzania (Ghiasy et al., 2018, p. 226). Lebih dari 60 negara akan terlibat dalam proyek belt dan road China dimana mayoritas adalah negara berkembang. Untuk melanggengkan mega proyek tersebut China berhasil membuat Silk Road Fund sebesar 40 miliar US dolar yang ini menjadi kendaraan pembiayaan infrastruktur untuk memasok pendanaan dalam membiayai pembangunan jalur sutera maritim dan infrastruktur lainnya (Ghiasy et al., 2018, p. 228).

China juga memanfaatkan program bantuan dalam BRI sebagai alat untuk menebar pengaruh ke negara-negara lain, terutama negara penerima bantuan. Bantuan China diimplementasikan melalui gagasannya mendirikan Asian Infrastructure Investment Bank (AIIB) yang merupakan lembaga pemberi pinjaman untuk proyekproyek pembangunan infrastruktur terkait kebijakan BRI, termasuk jalur sutera maritim China. AllB sebagai bank pembangunan multilateral membawa misi untuk meningkatkan penghasilan ekonomi dan taraf kehidupan sosial di Asia dan negara anggota lainnya. Bermarkas di Beijing, AllB sudah beroperasi sejak Januari 2016 dan mengalami kemajuan pesat dengan jumlah 57 anggota pendiri hingga bertambah menjadi 86 anggota negara di dunia (Zou Weikang, 2018).

Membangun jalur maritim China mempunyai tantangan dan hambatan yang lebih daripada jalur sutera darat. Jalur sutera lama yang membentang di daratan China hingga Asia tengah telah terbentuk sehingga China hanya perlu menghidupkan kembali dengan dukungan teknologi. Berbeda dengan jalur sutera maritim yang baru 
mulai dibangun dengan dukungan negara-negara maritim di sepanjang laut dan samudra.

Negara-negara di Asia menjadi prioritas utama untuk konektivitas. Selain Asia, China juga memberikan perhatian kepada negara-negara yang terletak di Samudra Hindia seperti Sri Lanka yang sangat strategis sehingga Menteri Luar Negeri China, Wang Yi, menjuluki negara ini sebagai "Dazzling pearl on the Maritime Silk Road". Negara di Samudra Hindia lain yang tidak kalah penting adalah Maladewa, dimana Presiden Xi Jinping telah melakukan kunjungan kenegaraan pada tahun 2014 silam dengan memperluas perdagangan dan sektor pariwisata yang ditandai dengan adanya Memorandum of Understanding (MoU) (Blanchard \& Flint, 2017). Selain itu, beberapa negara di Timur Tengah dan Afrika yang memiliki pelabuhan seperti Mesir, Irak, dan Iran juga telah memperluas integrasi politik dan diplomatiknya ke arah dukungan Jalur Sutera Maritim China demi mendapatkan keuntungan bersama.

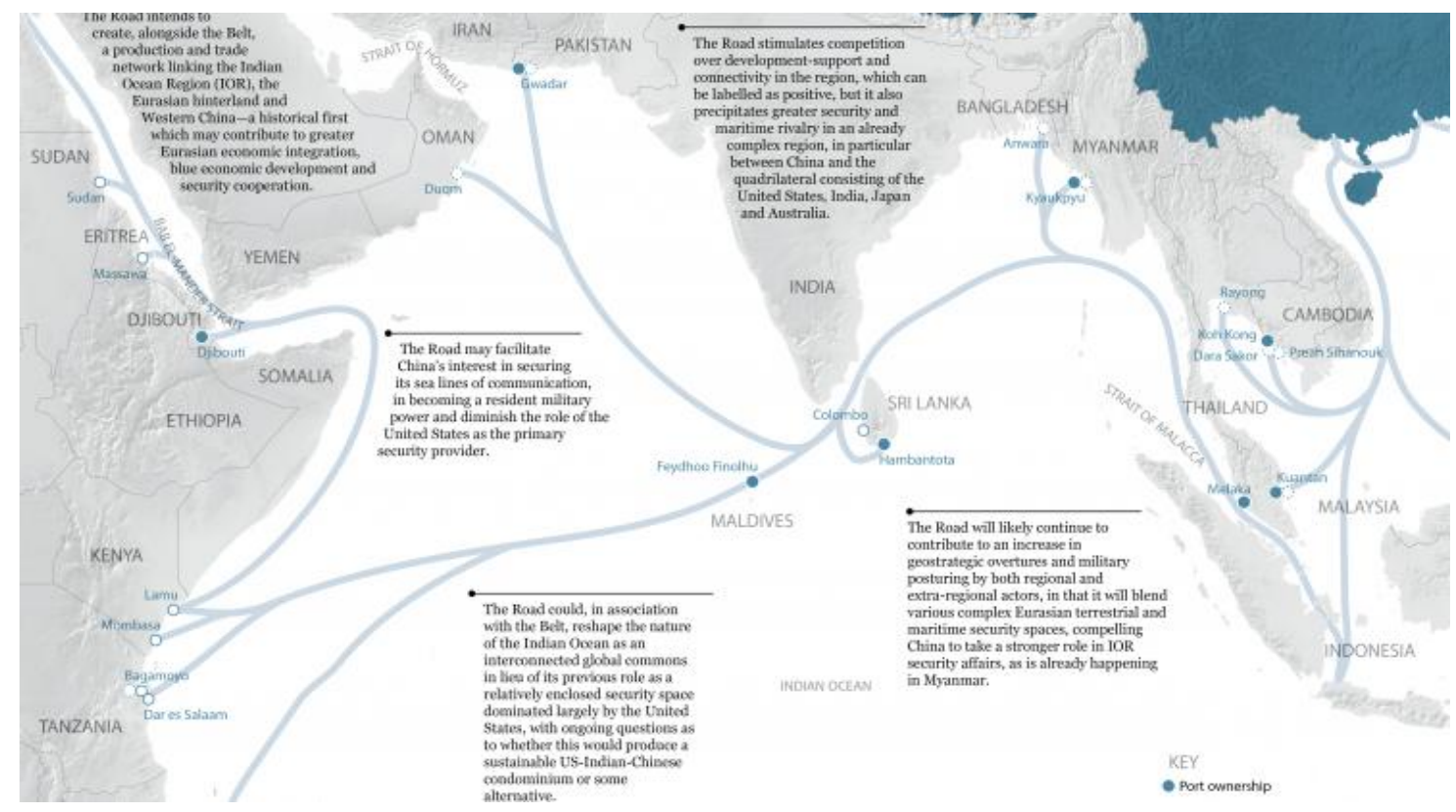

Gambar 3. Jalur Sutera Maritim China (Ghiasy et al., 2018)

\section{IMPLIKASI JALUR MARITIM CHINA TERHADAP SITUASI KEAMANAN DI ASIA TENGGARA DAN INDONESIA}

Ketika Presiden Xi Jinping menyampaikan gagasannya mengenai Silk Road Economic Belt dan Maritime Silk Road, yang menjadi fokus utama China ialah negaranegara Asia karena konektivitas BRI akan berlangsung diantara negara-negara Asia termasuk ekspansi untuk koridor ekonomi maritim yang hingga kini masih dalam tahap pembangunan (Jinping, 2017). Asia menjadi kunci bagi keberhasilan BRI China baik jalur darat maupun maritim. Untuk jalur sutera maritim akan membentang dari pesisir China timur kemudian memasuki Laut China Selatan yang dikelilingi oleh negaranegara Asia Tenggara. Maka, hampir semua negara Asia Tenggara memiliki peran besar bagi keberhasilan mega proyek China tersebut. 
Berbicara mengenai jalur maritim China yang melalui sejumlah wilayah laut di Asia Tenggara tentu mengingatkan pada konflik di Laut China Selatan yang belum kunjung usai hingga hari ini. Dari konsep keamanan maritim kita dapat melihat bagaimana keamanan sebuah wilayah perairan dapat tercipta bilamana tidak ada ancaman didalamnya. Permasalahan perbatasan laut yang tidak kunjung usai mendorong pada konflik antara negara-negara. Konflik yang melibatkan setidaknya delapan negara ini terjadi karena perbedaan pendapat mengenai garis batas teritorial masing-masing negara. klaim China di wilayah Laut China Selatan memang sebuah sejarah panjang karena menerapkan peta tradisional nine dash line yang memperluas wilayah China hingga ke utara perairan Indonesia. Laut China Selatan merupakan jalur pelayaran strategis dan penting bagi dunia karena menghubungkan Samudra Hindia dengan Laut China Timur melalui Selat Malaka. Fakta ini menunjukkan besarnya keuntungan ekonomis yang dapat diraup dalam wilayah perairan tersebut, ditambah lagi potensi kekayaan sumber daya alam yang terkandung didalamnya.

Dalam kacamata China, ASEAN memiliki tiga masalah keamanan; pertama, perselisihan dalam sengketa Laut China Selatan antara China dan empat negara anggota ASEAN lainnya; kedua, masalah kemakmuran dan stabilitas negara anggota; dan ketiga, masalah kohesifitas, keefektifan, dan kredibilitas ASEAN itu sendiri (Ghiasy et al., 2018). Tiga permasalahan ini menciptakan hubungan yang kurang harmonis bukan hanya dengan China tetapi juga sesama negara anggota ASEAN. Terdapat sejumlah sengketa yang belum diselesaikan antara China dan negara-negara Asia Tenggara. Seperti masalah perbatasan, perselisihan yurisdiksi peningkatan persenjataan hingga masalah perebutan sumber daya alam.

Masalah sengketa yurisdiksi di Laut China Selatan (LCS) antara China dengan beberapa negara ASEAN yang mengklaim yaitu Malaysia, Filipina, Vietnam dan Brunei Darussalam disebabkan oleh nine dash line China yang mengklaim hampir 80 persen luas dari LCS, muncul tumpang tindih serta konflik klaim kawasan maritim dan Zona Ekonomi Eksklusif (ZEE). Dengan Filipina, China belum selesai mengenai tarik ulur ZEE di wilayah Reed Bank, yang berlokasi 80 mil laut dari pulau Palawan. Sementara dengan Vietnam China bermasalah dalam survei seismik untuk minyak dan gas yang memicu konflik bersenjata (Warsito, 2015). Di satu sisi, klaim China bertentangan dengan kerangka kerja UNCLOS untuk zona maritim. Hal ini pernah dilaporkan oleh Filipina mengenai kasus eksploitasi sumber daya maritim. China mendapatkan teguran dari Mahkamah Arbitrase Internasional di Den Haag pada tahun 2016. Pada saat itu, China menolak mediasi internasional yang diajukan, sementara Vietnam dan Filipina tetap berusaha menjadikan isu ini sebagai kasus internasional.

Sebagai respon atas meningkatnya ketegangan di LCS, terlihat beberapa peningkatan persenjataan di negara-negara sekitar, misalnya Vietnam yang meningkatkan pengeluaran militernya sebesar 127 persen dari \$2,2 milyar pada tahun 2006 menjadi \$ 5 miliar pada tahun 2017. Pada saat itu, Vietnam menjadi negara di urutan ke-11 sebagai penerima senjata terbesar dunia. Vietnam juga memperlihatkan kedekatannya dengan Amerika Serikat, Jepang dan India dalam bidang keamanan. Sementara Filipina dan Thailand sejak tahun 2013 meningkatkan belanja militer secara konstan di Singapura. Di saat yang bersamaan China juga terus meningkatkan kapasitas militernya di LCS. Perkembangan ini membuat cemas negara-negara ASEAN terutama negara pengklaim dan berbagai stakeholder regional berkaitan 
dengan masalah kebebasan navigasi. Amerika Serikat sebagai negara yang memiliki kepentingan ekonomi dan keamanan cukup signifikan di LCS dan di Asia Tenggara telah melakukan kebebasan reguler untuk navigasi dan mendukung negara mitranya di Asia Tenggara.

Ditinjau dari potensinya, LCS adalah sebuah wilayah teritori yang kaya sumber daya alam. Dasar lautnya diyakini mengandung sekitar 11 miliar barel minyak dan 190 triliun meter kubik gas alam. Pengeboran minyak dan gas di wilayah yang bersengketa sebagian besar telah menimbulkan ketegangan politik. China pada tahun 2012 hingga 2016 memblokade nelayan Filipina di Scarborough Shoal, selain itu, Vietnam menghentikan ekspedisi pengeboran gas setelah mendapatkan tekanan dari China pada tahun 2017.

Menurut China, area penangkapan ikan ini seharusnya digunakan untuk tujuan keamanan pangan dan memperluas 'blue economy' (Ghiasy et al., 2018, p. 32). Persoalan isu keamanan laut bagi negara-negara "Island in Between" atau negaranegara di Asia Tenggara dengan berbagai klaim atas beberapa wilayah maritim yang strategis di LCS merupakan penyebab utama munculnya perselisihan antar negara. Disampaikan dalam tulisan Connie Rahakundini bahwa Craig Snyder mencoba menganalisis perselisihan dibalik isu keamanan maritim melalui tulisannya "Maritime Security in Southeast Asia" terdapat tiga faktor utama yang menurutnya mempengaruhi keamanan laut, yaitu: kepentingan atas kekayaan sumber daya laut dan ZEE (Exclusive Economic Zones), perubahan lingkungan keamanan regional pasca berakhirnya Perang Dingin dan mundurnya kekuatan militer Amerika Serikat di Asia Tenggara, serta keamanan maritim menjadi perhatian utama dari angkatan laut dalam mengatasi berbagai ancaman kedaulatan nasional yang berasal dari faktor eksternal seperti penyelundupan senjata, masalah narkoba, sampai imigran gelap.

Tiga wilayah yang sering menjadi perselisihan regional di Laut China Selatan adalah kepulauan Spartly, Paracel, dan Scarborough (Bakrie, 2007). Sebagaimana diketahui klaim China sejauh ini berdasarkan kekuatan histori yang kurang sesuai dengan hukum internasional. Pengaturan dalam UNCLOS 1982 bahwa kedaulatan atas wilayah laut tertentu diukur berdasar jarak dari titik atau pulau terluar suatu negara. Seiring dengan semakin menguatnya ekonomi dan militer yang dimilikinya, China bersikap lebih asertif dalam memperjuangkan kepentingannya.

Sementara Indonesia, untuk kasus LCS cenderung memilih berada dalam posisi netral dengan berdiri di zona aman. Ini merupakan sebuah sikap yang mencerminkan prinsip politik luar negeri Indonesia, yaitu bebas dan aktif. Tidak memihak pada salah satu kekuatan manapun. Namun sikap ini justru sangat disayangkan oleh negara tetangga, Filipina dan Vietnam, mengingat Indonesia sebagai pemimpin alamiah kawasan. Filipina pun berusaha melibatkan ASEAN. Namun, upaya Filipina membawa kasus Laut China Selatan ke forum KTT ASEAN di Kamboja tahun 2012 pun mengalami hambatan. Kegagalan tersebut tidak lain karena ditentang oleh sesama anggota ASEAN sendiri yaitu Kamboja, yang dikenal memiliki hubungan sangat erat dengan China (Suropati et al., 2016, p. 79). Kekecewaan terhadap hal tersebut membuat Vietnam dan Filipina cenderung lebih mendekat ke AS dalam menghadapi sengketa perbatasannya, pada saat yang sama Laos, Kamboja, dan Myanmar lebih condong ke China (Suropati et al., 2016, p. 65). 
Situasi keamanan di LCS ini menjadi batu sandung bagi kelancaran proyek Maritim Silk Road (MSR) itu sendiri. Akses untuk melampaui sejumlah zona perairan di sepanjang MSR idealnya adalah bebas dari ancaman dan sengketa. Indonesia, sekali lagi, sebagai negara yang memiliki prinsip politik bebas dan aktif memang tidak ikut campur dalam permasalahan negara lain, namun kebebasan China dalam membangun jembatan MSR tersebut patut ditinjau kembali demi mempertahankan keamanan nasional dan keamanan maritim Indonesia.

\section{JALUR SUTERA MARITIM CHINA SEBAGAI TANTANGAN SEKALIGUS PELUANG BAGI INDONESIA DAN SINERGISITAS TERHADAP KEBIJAKAN POROS MARITIM DUNIA}

Indonesia dikelilingi sejumlah laut dan selat strategis yang digunakan oleh berbagai negara dalam aktivitas pelayaran internasional. Beberapa diantaranya juga menjadi jalur yang dilalui oleh Maritim Silk Road (MSR) China, seperti; Laut China Selatan, Samudra Hindia, Selat Malaka, dan Laut Natuna. Wilayah laut ini banyak dimanfaatkan bukan hanya untuk menopang kegiatan ekonomi dan perdagangan, namun juga untuk kepentingan militer, politik dan keamanan. Banyak negara memiliki kepentingan di Laut China Selatan baik negara-negara Asia Tenggara, maupun negara-negara diluar kawasan. Hampir semua negara memanfaatkan laut ini untuk jalur perdagangan internasional maupun upaya memperluas pengaruh dikawasan. kekuatan laut yang dimiliki oleh sebuah negara dimaksudkan untuk melindungi kepentingan nasionalnya, termasuk China yang memaksimalkan kemampuan maritimnya di Laut China Selatan dengan orientasi blue economy yang mengarah pada bidang industri dan perdagangan (Blanchard \& Flint, 2017).

Pada konsep keamanan maritim dari Bueger, terdapat empat dimensi keamanan yang harusnya dipenuhi untuk mendapatkan situasi dimana keamanan maritim tercapai, yaitu keamanan nasional, keamanan ekonomi, keamanan manusia dan keamanan lingkungan maritim. Dalam hubungan internasional dikenal perspektif tradisional yang memandang bahwa keamanan nasional adalah hal terpenting bagi sebuah negara karena berkaitan kedaulatan. Keamanan nasional negara-negara Asia Tenggara masih terganggu dengan adanya ketegangan di Laut China Selatan, termasuk negara-negara non-claimant.

China diidentifikasikan sebagai negara dengan kekuatan militer yang paling besar dalam sengketa di Laut China Selatan, meskipun kehadiran Amerika Serikat juga masih nampak sebagai penyeimbang kekuatan militer. China seringkali membuat kebijakan-kebijakan luar negeri yang kontroversial dan negara ini mampu menempatkan diri sejajar dengan negara-negara pemilik teknologi pertahanan tingkat tinggi. Mencermati sepak terjang China belakangan ini, dengan menghitung untung rugi secara ekonomis dan politis, nampak China lebih memilih jalan yang bisa diartikan konfrontasi daripada negosiasi terhadap negara-negara di Asia Tenggara yang dipersepsikan lebih lemah secara militer. semua negara Asia Tenggara ikut mengantisipasi potensi konflik yang mungkin terjadi guna melindungi kedaulatan wilayah lautnya (Bakrie, 2007, p. 67), China mempersiapkan kekuatan militer bukan hanya memiliki kemampuan bertahan namun juga untuk kemampuan ofensif.

Salah satu bentuk strategi yang dilakukan China dalam upaya meredakan ketegangan namun tidak melepaskan kepentingan utamanya di LCS, negara ini 
mengajak negara-negara di Asia Tenggara termasuk Indonesia untuk bekerjasama melalui konsep MSR. Memperhatikan situasi konfliktual di kawasan, China sangat tepat mengambil langkah pendekatan ekonomi untuk meredakan ketegangan tersebut. Jalur maritim China yang membentang dari daratan China melalui Asia hingga ke Eropa dan Afrika melewati sejumlah negara, termasuk didalamnya Indonesia. Berkaitan dengan geopolitik China di kawasan Asia Tenggara, Indonesia menjadi salah satu negara transit yang paling diandalkan terutama pada sisi Selat Malaka. Bagi China, Indonesia adalah pusat ekonomi terbesar di Asia Tenggara, apalagi China menangkap sinyal kesamaan tujuan yaitu dengan deklarasi visi Indonesia dibawah pemerintahan Presiden Jokowi untuk menjadikan Indonesia sebagai titik tumpuan maritim global.

Disamping itu, bersama dengan inisiatif Poros Maritim Indonesia, Thailand juga ikut mendorong East Economic Corridor, yang bertujuan mengembangkan kawasan pesisir timur Thailand menjadi zona ekonomi terkemuka di ASEAN (Ghiasy et al., 2018, p. 26). Sebagai negara kunci dalam MSR China serta secara geografi berada tepat di selatan LCS, Indonesia memiliki peran signifikan dalam politik regional Asia Tenggara. Indonesia harus dapat mencari titik imbang antara kepentingan ekonomi, situasi politik dan mengedepankan keamanan negara. Secara geografis Indonesia merupakan negara kepulauan terbesar di Asia yang terdiri dari 17.506 pulau-pulau besar dan kecil, dimana 2/3 bagiannya merupakan perairan seluas lebih dari 5,8 juta $\mathrm{km}^{2}$ (Wahyono, 2007). Indonesia memiliki tanggung jawab untuk menjamin keamanan maritim baik untuk keutuhan bangsa Indonesia sendiri maupun keamanan maritim negara pengguna jalur pelayaran internasional yang ada di Indonesia.

Indonesia dibawah pemerintahan Presiden Joko Widodo mengembangkan sebuah konsep kelautan yang mengandung kepentingan strategis yaitu Poros Maritim Dunia (PMD). Dengan konsep PMD Indonesia diharapkan memiliki peran signifikan sebagai penghubung laut internasional. Sebagai bagian dari national interest, PMD adalah kebijakan pemerintah Indonesia yang telah disampaikan pada semua negara dan telah dimulai proses interkonektivitasnya. PMD berangkat dengan visi untuk menjadi negara maritim yang berdaulat, maju, mandiri, kuat, serta mampu untuk memberikan kontribusi positif bagi perdamaian di kawasan dan dunia sesuai dengan kepentingan nasionalnya. Wilayah laut Indonesia yang dipetakan sebagai MSR China terdapat di dua bagian, yaitu ALKI I dan Selat Malaka. Alur Laut Kepulauan Indonesia (ALKI) I, yang melintasi perairan Natuna dari Laut China Selatan menuju Samudra Hindia melalui Selat Sunda memiliki dua pintu masuk.

Pintu masuk pertama ditarik tegak lurus di tengah-tengah garis dasar yang menghubungkan Pulau Sentut dan Pulau Tokong Malangbiru yang memotong garis lurus yang lain dari pintu masuk kedua yang terletak di tengah garis dasar antara Pulau Senua dan Pulau Subi Kecil. Jalur ini memberikan kebebasan pelayaran bagi kapal asing. Semua kapal asing bebas berlayar di ALKI I dengan hak transit passage yang diakui oleh Konvensi Hukum Laut 1982, tanpa harus melapor kepada stasiun pantai RI, sehingga pengawasan kapal-kapal asing itu sangat perlu untuk ditingkatkan (Dam, 2010 , p. 119). Kembali pada konsep keamanan maritim yang mempertimbangkan keamanan nasional dimana Indonesia sebagai negara kepulauan yang terdiri dari pulau-pulau dan wilayah perairan didalamnya akan berhadapan dengan MSR China yang mengklaim jalur perairan Indonesia, sehingga kekuatan laut Indonesia harus 
dapat dimaksimalkan untuk memberikan perlindungan secara penuh dari agresifitas China di sepanjang koridor yang berada dalam perairan Indonesia.

Koridor ekonomi MSR China secara langsung bersinggungan dengan lautan Indonesia di beberapa wilayah. Keadaan ini membuktikan bahwa perairan Indonesia kedepannya akan semakin terbuka atas kepentingan ekonomi global. Disatu sisi, sengketa LCS mendorong peningkatan kekuatan militer negara-negara sekitar, sebagai negara terdekat tentu Indonesia akan mendapatkan imbas dari sengketa kawasan tersebut. Meskipun Indonesia tidak terlibat secara langsung dalam konflik LCS, namun klaim nine dash line China bersinggungan dengan wilayah teritorial Indonesia di bagian utara Natuna. Klaim China dalam nine dash line juga membawa dampak bagi Indonesia. Seperti beberapa kali terjadi insiden di Laut Natuna utara dengan China. Hal ini dipicu karena peta tradisional China yang menunjukkan wilayah penangkapan ikan tradisional hampir memasuki wilayah Indonesia.

Seperti insiden yang terjadi pada bulan Maret 2016, coast guard China membantu kapal nelayan China yang ditahan oleh Indonesia atas dugaan mencuri ikan. Selanjutnya pada bulan Mei 2016 China memprotes tindakan Angkatan Laut Indonesia yang menyita kapal China di dekat perairan Natuna, serta insiden ketiga bulan Juni di tahun yang sama dimana kapal perang Indonesia mendekati 12 kapal asing yang diduga mencuri ikan di laut Natuna (Muhaimin, 2016). Dalam dimensi lain konsep keamanan maritim, juga mempertimbangkan aspek keamanan ekonomi sebagai salah satu ancaman. Lautan Indonesia berkali-kali menjadi sasaran illegal fishing yang dilakukan oleh China dan beberapa negara lainnya. Ditambah lagi cara penangkapan ikan yang dilakukan oleh nelayan asing menimbulkan kerusakan lingkungan maritim. Hal ini tentu menimbulkan kerugian yang cukup besar bagi Indonesia.

Jalur MSR China menempatkan area teritorial Indonesia kedalam bagian kunci guna memperlancar gagasan tersebut setidaknya menimbulkan dua dampak. Pertama, ini akan memberikan dampak positif bagi Indonesia sebagai bagian yang dilalui oleh jalur perdagangan China. Keuntungan dari segi ekonomi dan politis sesuai dengan kemampuan diplomasi maritim Indonesia kepada China dan negara-negara sekitar. Pelaksanaan politik luar negeri Indonesia yang bertujuan untuk mengoptimalkan potensi kelautan guna memenuhi kepentingan nasional sesuai dengan ketentuan nasional dan hukum internasional. Sehingga Indonesia harus mampu memanfaatkan kerjasama dengan China terutama untuk pembangunan infrastruktur wilayah dan kawasan industri sebagaimana yang diatur dalam konsep jalur sutera maritim China (Suropati et al., 2016).

Kedua, tentu hal ini menjadi tantangan bagi Indonesia terutama dalam masalah keamanan dan ketertiban kawasan. Selain itu juga karena konsep jalur MSR belum terlalu jelas. Ketidakjelasan dapat menimbulkan kecurigaan dan multipersepsi yang akan berimbas pada pelaksanaan kerja sama yang tidak lancar. Hal seperti itu pernah terjadi di Sri Lanka, negara kecil namun memiliki geolokasi yang sangat strategis bagi kepentingan militer dan ekonomi China dimana negara tirai bambu ini memerlukan pelabuhan-pelabuhan pendukung bagi jalur perdagangan dan militernya. Dengan menunjuk Sri Lanka sebagai mitranya yang secara geostrategis berada di selatan India, memberikan kesempatan bagi China untuk menekan India dari selatan. Seperti yang disinggung dalam sub bahasan sebelumnya, bahwa jalur maritim China 
melalui Laut China Selatan mengandung banyak persepsi dalam kacamata keamanan oleh negara-negara Asia Tenggara tak terkecuali Indonesia (Suropati et al., 2016).

China pun secara aktif memilih dan menjadikan wilayah lautan Indo-Pasifik bersahabat dengan kepentingannya dengan mengembangkan kemitraan ekonomi dengan negara-negara di sepanjang rute MSR. Indonesia sebagai mitra strategis bagi China di satu sisi membutuhkan kesempatan kerjasama sebagai peluang ekonomi, namun disisi lain dihadapkan pada sejumlah potensi ancaman keamanan maritim. Melalui kacamata keamanan, sengketa yang melibatkan negara-negara tetangga di LCS memperlihatkan peningkatan persenjataan yang mengarah pada konflik terbuka. Sementara ide membangun MSR secara tidak langsung dapat memberikan kontribusi pada pembangunan kekuatan baik militer maupun pengaruh politik China di LCS. Muncul kekhawatiran di antara negara-negara Asia Tenggara bahwa China kelak bisa menggunakan strategi MSR tersebut sebagai bagian dari penetrasi militer di kawasan LCS.

\section{KESIMPULAN}

Artikel ini telah menjelaskan mengenai perkembangan China yang kian pesat dan semakin agresif dalam berbagai kawasan, termasuk Asia Tenggara. Hal tersebut menjadi peluang sekaligus ancaman bagi negara-negara di kawasan Asia Tenggara. Peningkatan kekuatan militernya beriringan dengan kekuatan ekonomi yang terus beranjak naik. Kebijakan politik dan keamanan China kemudian menjadi lebih terbuka dengan pembentukan kemitraan strategis dengan negara-negara lain. Keinginan yang disampaikan oleh Presiden Xi Jinping untuk mengarahkan kebangkitan China pada kontribusi perdamaian dan kemakmuran kawasan. Meskipun pada satu sisi, China masih dihadapkan pada permasalahan internal dan konflik di kawasan terutama sengketa Laut China Selatan. Hal tersebut menjadi batu sandung bagi China untuk mencapai tujuannya menjadi negara paling berpengaruh.

Untuk melindungi kepentingan ekonominya, China melakukan gebrakan dengan melakukan pengembangan strategi maritim. Bukan hanya mengedepankan kekuatan blue water navy, China juga membangun kembali kekuatan jalur sutera lama yang dikemas kembali dalam bentuk Belt and Road Initiative (BRI) yang didalamnya terdapat Maritime Silk Road (MSR). Hal ini berangkat dari semangat dari Jalur Sutera Kuno yang saat itu berkembang yaitu "peace and cooperations, openness and inclusiveness, mutual learning and mutual benefit'. MSR adalah salah satu prioritas dalam BRI dengan langkah awal memulai pembangunan infrastruktur di sepanjang jalur. Secara tidak langsung ini memberikan akses kepada angkatan lautnya untuk menggelar kekuatan maritim di wilayah lain.

Indonesia sebagai salah satu negara yang menjadi mitra strategis China karena secara geografis letak Indonesia sebagai negara maritim sangat mendukung ekspansi MSR. Tantangan utama yang dihadapi Indonesia adalah situasi keamanan maritim di kawasan dengan konflik LCS dan situasi keamanan maritim di sepanjang wilayah perairan Indonesia karena berkaitan dengan ancaman keamanan nasional misalnya pelanggaran kedaulatan. Menghadapi hal tersebut membutuhkan strategi politik luar negeri yang mengedepankan kepentingan keamanan maritim. Mengingat posisi Indonesia yang begitu strategis dalam kawasan, pemerintah sepatutnya mengambil 
langkah tepat dalam menanggapi mega proyek China dan menyelaraskannya dengan visi Indonesia sebagai Poros Maritim Dunia.

\section{REFERENSI}

Bakrie, C. R. (2007). Pertahanan Negara dan Postur TNI Ideal. Jakarta: Yayasan Obor Indonesia.

Blanchard, J.-M. F., \& Flint, C. (2017). The Geopolitics of China's Maritime Silk Road Inititive. Geopolitics, 22(2), 223-245. https://doi.org/10.1080/14650045.2017.1291503

Bueger, C. (2015). What is maritime security? Marine Policy, 53, 159-164. https://doi.org/https://doi.org/10.1016/j.marpol.2014.12.005

Creswell, J. (2007). Qualitative Inquiry and Research Design: Choosing Among Fire Traditions (2nd ed.). California: SAGE Publications.

Dam, S. (2010). Politik Kelautan. Jakarta: Bumi Aksara.

Ghiasy, R., Su, F., \& Saalman, L. (2018). The 21th Century Maritime Silk Road; Security Implications and ways forward for the European Union. Stockholm International Peace Research Institute (SIPRI). Retrieved form https://www.sipri.org/publications/2018/other-publications/21st-century-maritimesilk-road-security-implications-and-ways-forward-european-union

Huy Hoang, N. (2017). China's Strategic Moves since the Communist Party of China's 18th National Congress: Impact on ASEAN Security and Politics. In J. Jacob \& H. T. Anh (Eds.), China and its Neighbourhood; Perspectives from India and Vietnam. New Delhi: Pentagon Press.

Jati, I. (2017). Comparative Study of the Roles of ASEAN and the Organization of Islamic Cooperation in Responding to the Rohingya Crisis. IKAT: The Indonesian $\begin{array}{llll}\text { Journal of Southeast Asian Studies, } & 17 .\end{array}$ https://doi.org/10.22146/ikat.v1i1.27466

Jinping, X. (2017). The Governance of China II. Beijing: Foreign Languages Press.

Johnson, C. K., Cha, V., \& Searight, A. (2016, December 15). How should we view China's rise? Center for Strategic and International Studies. Retrieved form https://www.csis.org/analysis/how-should-we-view-chinas-rise

Mearsheimer, J. J. (2001). The Tragedy of Great Power Politics. W.W. Norton \& Company.

Muhaimin. (2016, June 20). Insiden Indonesia dan China di Natuna sudah tiga kali. Sindonews.

Retrieved

form

https://international.sindonews.com/read/1118077/40/insiden-indonesia-danchina-di-natuna-sudah-3-kali-1466385708

Raco, J. R. (2010). Metode Penelitian Kualitatif, Jenis, Karakteristik dan Keunggulannya. Jakarta: Grasindo.

Simamora, P. (2014). Peluang dan Tantangan Diplomasi Pertahanan. Yogyakarta: Graha IImu.

Suropati, U., Sulaiman, Y., \& Montratama, I. (2016). Arungi Samudra Bersama Sang Naga: Sinergi Poros Maritim Dunia dan Jalur Sutera Maritim Abad ke-21. Jakarta: PT Elex Media Komputindo.

Tempo.co. (2014, November 13). Cara Jokowi Jadikan Indonesia Poros Maritim. Retrieved form http://www.tempo.co/read/news/2014/11/13/118621707/CaraJokowi-Jadikan-Indonesia-Poros-Maritim 
The Editors of Encyclopaedia Britannica. (2018, September 19). Silk Road Trade Route. Retrieved form https://www.britannica.com/topic/Silk-Road-trade-route

Till, G. (2004). Seapower: A Guide for the Twenty-First Century. London: Frank cass.

Wahyono, S. (2007). Indonesia Negara Maritim. Jakarta: Teraju (Anggota IKAPI).

Warsito, P. T. (2015). Mengurai Silang-Sengkarut Sengketa di laut China Selatan. Seminar Nasional Universitas Muhammadiyah Yogyakarta.

Xinhua Net. (2018, August). Belt and Road Initiative. Retrieved form http://www.xinhuanet.com/silkroad/english/index.htm

Zou Weikang, P. (2018). The Belt and Road Initiative; implementation, coordination and international financial cooperation [PowerPoint]. Seminar Internasional dengan tema: South-South Cooperation for Developing Countries. 